\title{
Perspectives of Finland Female Design Education based on Finland Design Development
}

\author{
Yue ZHAO \\ Shandong Women's University, Jinan, Shandong, 250300, China
}

\begin{abstract}
Finland is honored as the country of design, and its capital Helsinki was awarded as "World Design Capital" in 2012 by World Industrial Design Association. Thanks to its excellent design tradition and education system, Finland achieves impressive grades and attracts attention of the world in design. As a state of feminism, women of Finland are equal to men to have the education opportunities and platforms showing their talents, female designers made great contribution to development of design in Finland. This paper tries to analyze the influence of Finland education to Finland design, especially female designers and the development of their design career through investigation to Finland design and design education. Whereby, we can also get some inspiration and reference there from.
\end{abstract}

KEYWORD: Design; Design Education; Finland; Female Design Education

\section{FINLAND DESIGN AND FEMALE DESIGNERS OF FINLAND}

\subsection{Finland design}

Finland design received attention of the world since the period of New Art Movement, "good function" and "minimal but artistic style" design concepts of the great design master Alva Alto are affecting development of modern design all the time. The world focused attention upon Finland again in 2012 and gave the evaluation that "everyone is a designer" to Finland and Finnish people are proud of this. Finland can have such achievements in design is because of their unique geographical environment, national tradition, educational ideas, policy support and factors of many other aspects.

\subsubsection{Characteristics of Finland Design}

Finland design is closely related to daily life because Finland is a country where life and development relies on design and the life of the Finns is based on design. Finland is situated at the high latitude and cold all the year round, in the era that its science and technology were under development, the Finns spent most of their time indoors in winter, good life quality therefore became a good wish of the Finns, and that is why traditional crafts and interior furnishings design are excellent in Finland. The selected texture of materials, the structure of buildings, functions of furniture, the artistic quality of interior furnishings, the construction of comfortable and warm indoor environment are the result of their wishes.

Following are the factors making Finland design be a miracle in the history of world design:

Be in touch with nature. Nature is the foundation, and intimacy with the nature is always expressed in design. The design may choose nature as the subject or choose natural material. The lakeshaped vase designed by Alva Alto, poppy flower patterns designed by Marimekko and wooden furniture can make people feel the charm of nature. Paying attention to environmental protection and maintaining biological balance are eternal theme in Finland design interpreting sincere treatment between human beings and the nature.

Good Function: One of the cardinal principles of Finland design is function first. Good function of design can bring people with convenience and pleasure of life, solving livelihood issues by design can not only make users learn how to use through design, but also guide users with new manner of living and attitude. In Finland, each design is considered delicately in every possible way, and all designs authentically reflect people-oriented design

Yue ZHAO (1973- ), female, Han nationality, born in Jinan, Shandong, art instructor of Shandong Women's University, master of artistic design, associate professor, research filed: artistic design and design education. Mailing address: No. 2399, Daxue Road, Changqing University Technology Park, Jinan City, Shandong Province. Post Code: 250300. 
concept, kitchen design is one of the remarkable achievements in Finland design, all kitchen utensils are arranged in a unified way, each object has its own space and position, the whole kitchen is clean and tidy, the design is deliberately made whether in kitchen layout or each utensil use. Take the utensil display stand as example, the design of which was originated in 1930s, the net-shaped display can be placed with utensils in order, it is handsome and space-saving, the space left between the utensils makes them easy to be dried and kept clean, the bottom of the open display stand offers an aerationdrying condition for utensils, putting the display on the top of the kitchen sink, the water on utensils could not wet the kitchen ware, this design is still be used by the Finns until date.

Gorgeous \& simple. Finns have sincere and earnest national character and serious life attitude; in the meanwhile, they have high requirements to living quality. Plain and simple design works reflect that they treat life sincerely, and the artistic expression is their pursuit to life quality. Therefore, even though their design works we see are simple, they always reveal a kind of artistic quality and charm which make life full of artistic atmosphere, the satisfaction to life and pleasure there from can be felt. Finland design is leading in the world based on their pursuit to such high quality. Innovation changing life is the expression of Finland design and the reflection of people's attitude towards life.

Respect to design. Design is updated very quickly, while it does not mean giving up previous excellent achievements, and the Finns respect their previous achievements. They are not just saving, but using new methods to spread their achievements. For example, the lake-shaped vase designed by the famous design master Alva Alto was awarded with Gold Prize in France Paris International Design Exhibition in 1913 which was the foundation for Finland design obtaining recognition of the world. Finns appreciate this master but respect his work more, they hope that this work can be spread, and they show the work of this master by a fresh new interpretation way. They change the way and material applied to show this work with hundreds of years' history to people with new style all the time. Almost each family owns his work in memory of this mater making contribution to his nation. Respect to this designer is reflected in each loop of design. People also respect new designers in the same way. Names of designers are marked on the label after each work is finished. It seems to be a minor matter, but it expresses respect to designers.

\subsubsection{Finland design and women}

Finland design is developed from life, in other words, design is for life, it is used to change living environment, improve living quality and show their pursuit and yearning to life through design.
Therefore, Finland design is closely related to life, in particular, the development of industries related with interior life is more outstanding, such as furniture, furnishings, textile, clothing, and accessories, household electrical appliance and electronic products. These designs have prominent Finland style, simple style, good function, elegant quality, artistic taste and intimacy to nature. That is why female designers in Finland have outstanding performance because women are dominant in family life. It is shown by the data of Finland Design Association in 2013 that female designers in Finland were $52 \%$. Finland is a state of feminism, and women have higher social status and enjoy same rights and opportunities as men. Therefore, women have advantageous platforms showing their talents. Coupled with geographical environment, the scope of Finland design is more related with family life. Thus, the advantages of female designers are displayed in Finland. Women's advantages are shown in their attention to family, good artistic sensibility, meticulous heart and women being good at create atmosphere with visual language.

\subsection{Female designers in Finland}

Most of design works of Finland are about family life, female designers are prominent in these brands and production creators. They make great contribution to development of Finland design and the idea of design changing life. Hereby take some excellent Finland design brands for example.

\subsubsection{Marimekko}

It is an international brand created by female designer with a history of over 60 years. In 1951, Ami Ritia and her husband initiated this brand, they committed themselves to design of knitwear and clothing, Marimekko has become a famous international brand since 1960s. Her growing cannot be separated from her acute observation and judgment to the market as a female and rich imagination and creation of designers, while $60 \%$ designers having critical function to development of this brand are women. Excellent female designers made great contribution to development and maturity of Marimekko.

\subsubsection{Littala}

It is a famous comprehensive design brand in Finland for home supplies. Main products are glass handcrafts, products for display and decoration, ceramics and kitchenware. Glass handcrafts are superb, and there are quite a few classic design works, such as Crcic water glass, Alvar Aalto vase, Toikka glass birds. Iittala becomes a supplier of high quality and taste life solutions with hundreds of years' reputation. For furniture display, contributions 
of female designers to development of this brand cannot be neglected. Anio Aalto was Alvar Aalto's wife, and Finns are still fond of the glassware designed by her after 70 years. Her glassware design work won Gold Prize of Milan Design Exhibition in 1932. Her design concept is providing simple happiness to the young and the old. People are infected by the simple style with rhythm sensation, transparent texture, noble and elegant artistic quality.

Excellent female designers of Finland emerge in endlessly because of their pursuit to life, living style, respect to female and respect to designers. Besides these famous international design brands in Finland, you will find stores of designers in each city, especially stores of female designers for textile, jewelries and ornaments, all of them have highdefinition individual characteristics. They are weaving beautiful life with their exquisite heart.

\section{GENDER PERSPECTIVE IN FINLAND DESIGN EDUCATION AND EDUCATION}

Besides geographical environment and cultural environment, another more important factor for female Finland designers obtaining such impressive achievements is excellent education in Finland. Students in Finland grow up gradually in a kind of free and relaxed learning environment.

\subsection{Free atmosphere-from elementary education to college education}

Education in Finland is always maintained in relaxed and happy atmosphere. Learning interests of students will be motivated and potencies of students will be developed in such atmosphere so that students will learn consciously and happily. Education is conducted as per intention and natural endowment of students, they do not spoil things by excessive enthusiasm and they respect personality development of students. Compared with students in Asia, learning of students in Finland before middle school is very relaxed and free, the emphasis of primary school is training learn interests and basic learning ability of students and making pursuit of knowledge become a desire and joy. Along with gradual mature of students' personality and enhancing of learning ability, students will absorb a lot of knowledge and improve independent study ability after middle school. This kind of free learning is reflected in all aspects of teaching, especially in their elective system and teaching approaches. Hereby introduce excellent experience of education in primary school and college education because this is the beginning of education and core of learning [1].

Elective system. Students have many elective courses since primary school, it can be seen from investigation of Lapland University and its affiliated primary school, and students can choose their favorable courses according to their interests, hobbies and capabilities. Classes are not fixed in college, students choose courses according to their major demands and development direction. This way shows respect to intention of students and make students make full use of their advantages, selection of students is better for them to learn as per their own will and plan.

Teaching approach. Teaching approach is the core loop in teaching, it is not only accumulation of knowledge emphasized in primary education, learning interests and training of ability are emphasized more so that students will learn to know the world, care the world and change the world. Training of thinking mode and application abilities are emphasized more in colleges. Students will be taught how to think about problems and solve problems. Teachers will guide students to master the abilities of how to find, think, know, analyze, judge and solve problems. Knowledge becomes necessary support in the course, it expands the scope of knowledge but more important is learn how to possess resources, use resources and finally solve social issues effectively. In this way, students always maintain high degree enthusiasm and initiative and open the door to mysteries in their own way. Teaching program in Finland is a directional guidance, and teachers can decide what students learn and how to learn in their sole discretion according to students' condition. Such free atmosphere not only motivates teachers' sense of responsibility and enthusiasm, but also mobilizes students' initiative and creativity.

\subsection{Consciousness of innovation}

Consciousness of innovation is the concept of education and the purpose of education, the key point is how to train consciousness of innovation effectively. This concept runs through the entire education course in Finland. Teachers emphasize to train consciousness of innovation of students and give certain inspiration to students in the course of teaching and students can interpret as per their own will and understanding. For example, in the art curriculum of primary school, there is no copy, teachers just give subjects, describe scenes that everybody knows and set basic conditions, students will paint according to their experience. All works are individual creation under the same subject, students can see different experience, and they will compare and find more wonderful things. This allows students give play of their personalities and enriches students' imagination. This kind of teaching approach is up to colleges, students already have their own way of expression and personality characteristics, exploration and innovation have 
become their pleasure and habit. What needs to be mentioned here is that design education in China is also adhering to the concept of innovation all the time, but this kind of education is not just trained in colleges, the habit of thinking is cultivated from childhood, more effort is needed to change for adults.

\subsection{Gender perspective in Finland education}

Education experience of from different aspects, education from families, education from society and education from educational institutions affect people's growing from different angles in different stages. Finland is a state of feminism, the principle of respecting women and emphasizing women is always maintained in the course of education. Women in Finland can always enjoy equal status and opportunities same as men in education of families, education of educational institutions and education of society. This tradition makes Finnish women always have good stages to accept education and show their talents.

\subsubsection{Psychological hint in female education}

Education is divided into direct education and indirect education, psychological hint of indirect education has deep influence to the result of education. Psychological hint is an unexplainable guidance in education, it is not accepted and felt directly by people accepting education, but it has deep influence to people accepting education, this kind of psychological conquer may affect their whole life. People are results of comprehensive education integrated with family education, school education and social education. Their effect to people's growing in each stage and environment cannot be neglected. Education of family is the enlightenment stage of education, the awareness of parents to gender will permeate the initial awareness of social gender perspective over time. Code of conduct of girls and future expectation of boys will imprint in people's heart so that he/she will always understand and plan their behaviors and future, and even themselves. In the course of education in educational institutions, we do not advocate distinguish of genders, but there will be various gender problems in education which directly reflect different education and different education results because of different genders. Maybe this is not the real intention of education, but the actual result distinguishes gender. More boys are interested in science, more girls are interested in arts, boys are smarter, and girls are more emotional [2]. The idea formed unconsciously will invisibly influence students' psychology and selection of education and even selection of life. Compared with education from families and educational institutions, influence of social education to people can reflect distinguish of gender further more. Gender is mainly reflected in physiological features, men and women play different roles in families because of different physiological functions so that different career orientation is generated, this directly forms different careers with gender orientation and facilitates formation of social personality of women so that people's gender property is really reflected on the platform of society. This kind of social education hint comes from people's topics, discussion and attention......For this reason, we can feel such education hint is the key factor forming social gender of women. This kind of hint is giant energy hidden under the surface and it is the driving force of superficial phenomenon.

\subsubsection{Disregard of gender in Finland education}

Thanks to such free and relaxed learning atmosphere and emphasis to innovative consciousness, education of women is the same as men. As a state of feminism, Finland always pays attention to development of women. Women have equal status with men in families and society and space putting their talents to good use. Their education is a kind of non-female women's education which reflects the sense of equality [3] between men and women more.

Gender is an important social constraint and also a kind of invisible social dynamics. In Finland, demand of gender is used to strengthen gender equality and weaken gender difference. Gender is ignored during the course of education; disregard of gender weakens gender consciousness in order to reach equality of gender consciousness. In Finland, mobility of education is emphasized in education, the concept of gender is not emphasized in education, but more encourages and opportunities will be given to women so that women can recognize their potentials and abilities. On the contrary, women can really feel equality between men and women and respect to women in this kind of non-gendered education. In the investigation, more than $90 \%$ women think that there is no different with men in learning and work, which further affect new education course and education environment. Therefore, women are as wonderful as men in Finland. We can tell gender condition in Finland design industry from a group of figures: It is shown by the investigation of Finland Design Association in 2012 that $52 \%$ of Finland designers were female, and there were $60 \%$ female teachers in design education, $80 \%$ female professors. Among students of design major, $70 \%$ female in undergraduate education, $80 \%$ female in postgraduate education, and over $90 \%$ female in doctor education. Even though it cannot reflect the entire situation, it can reflect education result in Finland from the side. 


\section{USE FOR REFERENCE}

Finland has excellent education system and education achievements which have been recognized by the world, and there are more outstanding achievements in female design education. The writer thinks that it essence corresponds to philosophical concept of Lao $\mathrm{Zi}$, comply with natural rules, do not act recklessly, it is not necessary to emphasize on purpose; people first, do not change deliberately and strengthen unnatural rules. While education shall be like the personality of water, do not change her, but nourish her, that is so-called "be as good as water". Provide women with nutrient, air and sky, women will release their potential abilities naturally and put their extraordinary talents to good use.

In China, women obtained special education since the ancient time, women were in special social status in feudal society, education of women was standardized after the May $4^{\text {th }}$ Movement in modern times. People also gave women social cognition different from men, some talents of women were developed in such kind of education environment, but some aspects were restrained. In modern society, reform and opening up policies mainly brought liberation of concept, women's education in China was change fundamentally, it was strongly advocated to train women's consciousness of independence and ability of self-supporting, women's education has been developed significantly so far.

Training of female design talents is important treasure which cannot be ignored, and women shall have sufficient space and opportunities to put femininity and advantages to good use especially in the society led by knowledge industry nowadays. Based on national conditions and cultural traditions of China, we shall learn excellent experience of other countries to spread the spirit of our cultural thoughts.

\section{REFERENCES}

[1] Fang Hai, Finland Modern Design Education, Journal of Guangdong University of Technology, 2012, (01): 66-71

[2] Shi Jinghuan, World Women Education, Jilin People's Education Press 2011

[3] Liu Zuoyang, Finland Women and Higher Education in the Course of Social Equalization, Comparative Education Study, 2005 (7): 48-51 